\title{
Primary Cutaneous B-Cell/T-Cell (Non- MF/SS) Lymphoma N3 TNM Finding v8
}

National Cancer Institute

\section{Source}

National Cancer Institute. Primary Cutaneous B-Cell/T-Cell (Non-MF/SS) Lymphoma N3

TNM Finding v8. NCI Thesaurus. Code C141381.

Involvement of central lymph nodes. (from AJCC 8th Ed.) 